\title{
Calcium sulfate ameliorates the effect of aluminum toxicity differentially in genotypes of highbush blueberry (Vaccinium corymbosum L.)
}

\author{
M. Reyes-Díaz ${ }^{1,2 *}$, C. Meriño-Gergichevich ${ }^{3}$, E. Alarcón ${ }^{3}$, M. Alberdi ${ }^{1,2}$ and W.J. Horst ${ }^{4}$ \\ ${ }^{1}$ Departamento de Ciencias Químicas y Recursos Naturales, Facultad de Ingeniería, Ciencias y Administra- \\ ción, Universidad de La Frontera, Temuco, Chile. ${ }^{2}$ Center of Plant, Soil Interaction and Natural Resources \\ Biotechnology, Scientific and Technological Bioresource Nucleus (BIOREN-UFRO), Universidad de La \\ Frontera, Temuco, Chile. ${ }^{3}$ Programa de Doctorado en Ciencias de Recursos Naturales, Universidad de La \\ Frontera, Temuco, Chile. ${ }^{4}$ Institute of Plant Nutrition, Leibniz University Hannover, Herrenhaeuser Stasse 2, \\ 30419 Hannover, Germany. *Corresponding author: reyesm@ufro.cl
}

\begin{abstract}
The effect of gypsum $\left(\mathrm{CaSO}_{4}\right)$ amendment in the reduction of $\mathrm{Al}$ phytotoxicity of blueberry cultivars differing in Al resistance (Legacy and Brigitta, Al-resistant and Bluegold, Al-sensitive) was studied in a Hoagland's nutrient solution under acidic conditions for 2 weeks. Treatments were: Control (Hoagland solution), $2.5 \mathrm{mM}$ $\mathrm{CaSO}_{4}, 5 \mathrm{mM} \mathrm{CaSO}_{4}, 100 \mu \mathrm{M} \mathrm{Al}\left(\mathrm{AlCl}_{3}\right), 100 \mu \mathrm{M} \mathrm{Al}+2.5 \mathrm{mM} \mathrm{CaSO}_{4}, 100 \mu \mathrm{M}$ $\mathrm{Al}+5 \mathrm{mM} \mathrm{CaSO}_{4}$. Physiological, biochemical and chemical features of leaves and roots were determined to establish the amendment efficiency in the reduction of $\mathrm{Al}$ toxicity in these cultivars. Results showed that under Al toxicity the three investigated cultivars accumulated high $\mathrm{Al}$ concentrations in leaves and roots. These concentrations decreased with $\mathrm{CaSO}_{4}$ application. Statistically significant interactions among $\mathrm{Al}$ in leaves but not in roots $(p=0.719)$ and cultivars $(p<0.001)$, were found. The lowest $\mathrm{Ca}$ concentration was found in the most Al-sensitive cultivar (Bluegold) and the highest in the more Al-resistant cultivars (Legacy and Brigitta). Among the underlying processes affected by Al stress in these blueberry cultivars the most evident changes were exhibited by the Al-sensitive cultivar Bluegold, where the photosynthetic performance decreased showing a slight recovery in presence of gypsum amendment at the end of experiment. Instead, the more Al-resistant cultivar (Legacy) did not change its photosynthetic parameters in presence of the gypsum amendments during the treatment, whereas in Brigitta, only a slight recovery at the end of treatment was evidenced by the gypsum application. Thus, in relation to these parameters the gypsum amendment was efficient in complete recovery from the toxic $\mathrm{Al}$ effect in the Al-resistant cultivar Brigitta and a slight recovery of the toxic $\mathrm{Al}$ effect in the Al-sensitive cultivar Bluegold. Nonetheless, this amendment is a good alternative to ameliorate $\mathrm{Al}$ toxicity in Al-sensitive cultivars and additionally provides a good source of $\mathrm{Ca}$ and $\mathrm{S}$.
\end{abstract}

Keywords: Acid soils, aluminium, amendments, calcium, gypsum. 


\section{Introduction}

Soils derived from volcanic materials (Andisols) are frequent in Southern Chile. They are characterized principally by high organic matter (OM), low phosphorus $(\mathrm{P})$ availability, and acidity $(\mathrm{pH} \leq 5.5)$ (Mora et al., 1999; 2002), as well as low contents of calcium and magnesium (Meriño-Gergichevich et al., 2010). In these soils a main problem is the acidity, determining the presence of toxic and available forms of trivalent aluminum $\left(\mathrm{Al}^{3+}\right)$ in the soil solution (Borie and Rubio, 2003), which is very detrimental for plants (Poschenrieder et al., 2008; Ryan and Delhaize, 2010). Toxic $\mathrm{Al}^{3+}$ results primarily in a reduction of root growth (Mora et al., 2004) and eventually overall plant toxicity (Kochian, 1995) reducing crop yields (Mora et al., 1999; Bolan et al., 2003). The reduction of root growth is due to the interaction of $\mathrm{Al}^{+3}$ with the dividing and expanding cells of the root elongation zone, inhibiting root elongation (Sivaguru and Horst, 1998; Rangel et al, 2007). As consequence water and nutrient uptake are diminished (Foy et al., 1978; Delhaize and Ryan, 1995). Other important and common effects of $\mathrm{Al}^{3+}$ on plant cells are the overproduction of oxygen reactive species (ROS) (Blokhina et al., 2003; Ma, 2005) and lipid peroxidation (LP). Lipid peroxidation induces alterations in the plasma membrane integrity and functionality (Tamas et al., 2006), resulting in nutritional and metabolic disorders (Pavlovkin et al., 2009) not only at the root level but also in the upper organs of plants (Reich et al., 1994; Peixoto et al., 2002). Enzymatic and non-enzymatic antioxidant systems can regulate the scavenging of ROS in plants (Shao et al., 2008). A greater leaf antioxidant capacity was found in leaves of Citrus reshni under Al toxicity coinciding with an augmented requirement for scavenging reactive species (Chen et al., 2005.). The photosynthetic performance is also al- tered under Al stress in some plants such as sorghum cultivars (Peixoto et al., 2002) and citrus rootstocks (Pereira et al., 2000), among others.

To reduce $\mathrm{Al}$ toxicity in acid soils and to overcome Al phytotoxicity a frequent practice is the employment of $\mathrm{Ca}$ amendments (Toma and Saigusa, 1997; Mora et al., 2002) such as lime, gypsum or phosphogypsum (PG) (Campbell et al., 2006; Takahashi et al., 2006a,b). The beneficial Ca effects in ameliorating Al toxicity in different crops growing in acid soils are reported by Illera et al. (2004) and Mora et al. (2002). Meriño-Gergichevich et al. (2010) reviewed the $\mathrm{Al}^{3+}$ $\mathrm{Ca}^{2+}$ interaction in plants growing in acid soils in comparison to the Al-phytotoxicity response to calcareous amendments and pointed out the importance of gypsum amendments in the reduction of toxic $\mathrm{Al}$ without altering $\mathrm{pH}$ conditions (Franzen et al., 2006). This occurs due to the replacement of exchangeable $\mathrm{Al}^{3+}$ by $\mathrm{Ca}^{2+}$ particularly in the subsoil and the formation of Al-hydroxyl-sulfate or aluminum sulfate complexes (Mora et al., 2002), which are less toxic to plants.

In current years, highbush blueberry (Vaccinium corymbosum L.) has been positioned as an important crop in southern Chile due to its high antioxidant capacity, which is believed to be good for human consumption and for economic return. The crop is well established on Andisols between $34^{\circ}$ and $44^{\circ} \mathrm{S}$ (INE, 1998; Besoain, 1999) especially in the "La Araucanía" region and with less importance in the most southern "Los Ríos" and "Los Lagos" regions of Chile. Although this species is well adapted to acid soils (Ireland and Wilk, 2006), it is very sensitive to $\mathrm{Al}^{3+}$ which constitutes a problem for its productivity (Korcak, 1992; Yang et al., 1996; Blatt and Mc Rae, 1997; Suzuki et al., 1999). Physiological and biochemical features of this plant species in response to Al toxicity has been poorly studied. Reyes-Díaz et al. 
$(2009 ; 2010)$ reported that short and long term Al toxicity affected differentially the effective photochemical efficiency of photosystem II (PSII) in highbush blueberry genotypes.

The possibility to employ amendments such as gypsum $\left(\mathrm{CaSO}_{4}\right)$ which reduce $\mathrm{Al}$ phytotoxicity without significantly changing the $\mathrm{pH}$ resulting in increased crop yield on Andisols (Mora et al., 1999) is a very important agronomic practice for crops, which demand acidity for their growth and development, but are sensitive to toxic $\mathrm{Al}$ as in the case of $V$. corymbosum (see above). However, little is known about the effects of $\mathrm{CaSO}_{4}$ on the physiological and biochemical traits in this plant species. Therefore, the aim of this work was to study whether $\mathrm{CaSO}_{4}$ is able to ameliorate the negative effects of $\mathrm{Al}$ toxicity on genotypes of highbush blueberry through determining some functional and chemical characteristics of root and leaves.

\section{Materials and methods}

\subsection{Plant Material}

One-year-old saplings of three highbush blueberry cultivars (cv), with different $\mathrm{Al}$ resistance, (Al-resistant Legacy and Brigitta and Al-sensitive Bluegold), frequently cultivated in southern Chile (Guerrero, 2006; Reyes-Díaz et al.,2009; 2010) were used for this study. Plants of these genotypes were in vitro produced and provided by Berries San Luis, Lautaro, Chile. Two groups of saplings were conditioned in plastic boxes filled with $18 \mathrm{~L}$ of Hoagland's nutrient solution (Hoagland and Arnon, 1959) for 2 weeks. One group of saplings was used for physiological and biochemical analyses and the other group was used for growth determinations (see below).

After conditioning, all saplings were subsequently transferred to a Hoagland hydroponic solution with increased $\mathrm{CaSO}_{4}$ concentrations $(2.5$ and $5 \mathrm{mM})$ without and with $\mathrm{Al}\left(\mathrm{AlCl}_{3}\right)$ in a toxic concentration $(100 \mu \mathrm{M})$ during 15 days and continuous aeration in a greenhouse. The individual treatments were: Control (Hoagland solution), $2.5 \mathrm{mM} \mathrm{CaSO}_{4}, 5 \mathrm{mM} \mathrm{CaSO}_{4}$, $100 \mu \mathrm{M} \mathrm{Al}, 100 \mu \mathrm{M} \mathrm{Al}+2.5 \mathrm{mM} \mathrm{CaSO}_{4}, 100 \mu \mathrm{M} \mathrm{Al}$ $+5 \mathrm{mM} \mathrm{CaSO}_{4}$.

The solutions were prepared with sterile deionized water and were filter-sterilized through $0.2-\mu \mathrm{m}$ pore diameter filters as described by Reyes-Díaz et al. (2009). The $\mathrm{pH}$ of the control (without Al) and all treatments solutions was monitored with a portable pH meter (model pH-0.13; Hi-Tech-Instruments, Shanghai, China) and adjusted daily to a $\mathrm{pH}$ of 4.5 using $0.1 \mathrm{M} \mathrm{HCl}$. Greenhouse growth conditions were $25 / 20^{\circ} \mathrm{C}$ (day/night), a 16/8-h (light/ dark) photoperiod, $300 \mu \mathrm{mol} \mathrm{m}{ }^{-2} \mathrm{~s}^{-1}$ photosynthetic photon flux (PPF), and $70 \%$ relative air humidity. After treatments, roots were washed three times with double distilled water as described in Yamamoto et al. (2001). During the experiment, in vivo measurements of chlorophyll fluorescence and $\mathrm{CO}_{2}$ assimilation were made at different times. At the end of the experiment, growth was determined and biochemical measurements were performed in roots and leaves from five individual plants per treatment as described below. For biochemical analyses, samples were harvested and stored at $-80{ }^{\circ} \mathrm{C}$ until use.

\subsection{Chemical analysis}

Mineral element concentrations in leaves and roots Calcium and Al concentrations were determined according Sadzawka et al. (2007), using a simultaneous multi-element atomic absorption spectrophotometer (model UNICAM 969 Atomic absorption Spectrometer, England). Harvested leaves and roots were dried separately in a forced-air oven at $70^{\circ} \mathrm{C}$ for $72 \mathrm{~h}$ and immediately ground. Samples were ashed at $500{ }^{\circ} \mathrm{C}$ for $8 \mathrm{~h}$, treated with $2 \mathrm{M}$ hydrochloric acid and $\mathrm{Ca}$ 
and $\mathrm{Al}$ was quantified using atomic absorption spectrophotometry

For sulfur (S) determination, the turbidimetric method described by Sadzawka et al. (2007) was followed. The samples (leaves and roots) dried for $48 \mathrm{~h}$ were treated with $95 \%$ magnesium nitrate $\left(\mathrm{MgNO}_{3} \mathrm{x}\right.$ $\left.6 \mathrm{H}_{2} \mathrm{O}\right)$ and ashed at $500^{\circ} \mathrm{C}$ for $8 \mathrm{~h}$. Then the ashed samples were digested for $60 \mathrm{~min}$ in $10 \mathrm{~mL}$ of $2 \mathrm{M}$ $\mathrm{HCl}$ at $150{ }^{\circ} \mathrm{C}$ and after addition of barium chloride $\left(\mathrm{BaCl}_{2}\right)$ and Tween-80 solution measured in an UVVIS spectrophotometer (UNICO ${ }^{\circledR} 2800$ UV/VIS, Spain) at $440 \mathrm{~nm}$.

\subsection{Physiological and biochemical analysis}

\section{Plant growth analysis}

Growth was analyzed by determining the change in fresh weight of 5 plants from the beginning (W1) to the end of the treatment (15 days) (W2). Growth was expressed as the mean relative growth rate (MRGR) from the mean natural logarithm-transformed weight plants: $M R G R=(\ln W 2)-(\ln W 1) /(\mathrm{t} 2-\mathrm{t} 1)($ Hoffmann and Poorter, 2002), where $t 1$ and 2 represent 0 and 15 days, respectively.

\section{$\mathrm{CO}_{2}$ assimilation}

$\mathrm{CO}_{2}$ assimilation was determined in vivo on attached leaves from the second to fourth node of shoots using a portable $\mathrm{CO}_{2}$ infrared gas analyzer (Licor LR6400, LI-COR Bioscience, Inc., Lincoln, Nebraska, U.S. \& Canada) equipped with a cuvette which controlled the light source $\left(300 \mu \mathrm{mol} \mathrm{m} \mathrm{m}^{-2} \mathrm{~s}^{-1}\right)$, temperature $\left(20^{\circ} \mathrm{C}\right)$, humidity and $\mathrm{CO}_{2}$. External $\mathrm{CO}_{2}$ from air was applied to obtain a reference concentration of $360 \mathrm{ppm}$, with a flow rate of $200 \mathrm{~mL} \mathrm{~min}^{-1}$ and $80 \%$ external relative humidity.

\section{Chlorophyll a fluorescence parameters of PSII}

Leaf chlorophyll-a fluorescence from the second to fourth node of shoots was measured using a portable pulse-amplitude modulated fluorimeter (FMS 2; Hansatech Instruments, King's Lynn, UK) to determine the photochemical efficiency of PSII according to Reyes-Díaz et al. (2009). The fluorescence parameters maximum quantum yield ( $\mathrm{Fv} / \mathrm{Fm})$, effective quantum yield (ФPSII) and electron transport rate (ETR) were estimated as described by Maxwell and Johnson (2000).

\section{Lipid peroxidation}

In fresh material of leaves and roots, the thiobarbituric acid-reactive substances (TBARS) were measured using Heath and Packer's method (1968) modified by Du and Bramlage (1992). In this modified procedure, the absorbance was measured at 532, 600, and $440 \mathrm{~nm}$ to correct for the interference produced by TBARS sugar complexes.

\section{Radical scavenging activity}

The radical scavenging activity (RSA) of roots and leaves was performed using the method of free radical 2.1-diphenyl-1-picrylhydrazyl (DPPH) scavenging as described by Chinnici et al. (2004), with some modifications. The absorbance was measured at $515 \mathrm{~nm}$ using Trolox as standard.

\section{Superoxide dismutase activity}

The frozen plant material was homogenized in 50 $\mathrm{mM}$ pH 7.0 potassium phosphate buffer $\left(\mathrm{K}_{2} \mathrm{HPO}_{4}^{-}\right.$ $\mathrm{KH}_{2} \mathrm{PO}_{4}$ ). The homogenate was centrifuged at $4^{\circ} \mathrm{C}$ 
for $15 \mathrm{~min}$ at $11,000 \mathrm{~g}$, and the supernatant was used as enzyme extract. Superoxide dismutase (SOD; EC. 1.15.1.1) activity was assayed by measuring the inhibition of the photochemical reduction of nitroblue tetrazolium (NBT) and measured using an UV-VIS spectrophotometer (UNICO® 2800 UV/VIS, Spain) at $560 \mathrm{~nm}$. One SOD unit was defined as the amount of enzyme corresponding to $50 \%$ inhibition of the NBT reduction (Donahue et al. 1997). SOD activity was calculated on a protein basis. The protein concentration in the enzyme extracts was measured spectrophotometrically using the method described by Bradford (1976).

\subsection{Experimental design and statistical analysis}

The experiment was arranged as a split-plot design with 3 genotypes x 6 treatments $\times 5$ replicates each. We used three boxes for treatments and their position with 5 plants each was changed every day to minimize positional effects. In vivo measurements of photochemical parameters of PSII and of photosynthesis were taken at 0-1-3-6-10-15 days. Growth, $\mathrm{Ca}, \mathrm{S}$ and Al concentrations, lipid peroxidation, radical scavenging capacity and SOD activity were determined at the end of the experiment after 15 days of treatment. For statistical analysis, reported values correspond to the mean of five individual replicates for each cultivar, treatment and time. All data were subjected to the normality and equal variance tests according to Kol-
mogorov-Smirnov. Data were then subjected to a twoway analysis of variance (ANOVA) (where the factors were genotypes and treatments) for chemical and biochemical analyses and to a three-way ANOVA (where the factors were genotypes, treatments and times) for in vivo measurements. A Tukey test was used to identify means with significant differences. Both analyses were performed with Sigma Stat 2.0 software (SPSS, Chicago, IL). Differences between the means were considered significant at $p \leq 0.05$.

\section{Results}

\subsection{Plant chemical analysis}

\section{Al concentrations}

Aluminum treatment alone significantly increased the $\mathrm{Al}$ concentrations of roots and leaves of all cultivars with cultivars Brigitta $>$ Legacy $>$ Bluegold in the leaves (Figure 1). $\mathrm{CaSO}_{4}$ treatment reduced $\mathrm{Al}$ concentrations in leaves and roots. Roots showed higher $\mathrm{Al}$ concentrations than leaves under $\mathrm{Al}$ treatment (100 $\mu \mathrm{M})$ without cultivar differences. Root Al concentrations were also greatly reduced by $\mathrm{CaSO}_{4}$ supply with respect to $\mathrm{Al}$ treatment alone but not to the control level even at the highest $\mathrm{CaSO}_{4}$ supply (Figure 1). ANOVA revealed a significant interaction between cultivars and treatments for leaves $(p \leq 0.01)$ but not for roots $(p=0.719)$. 


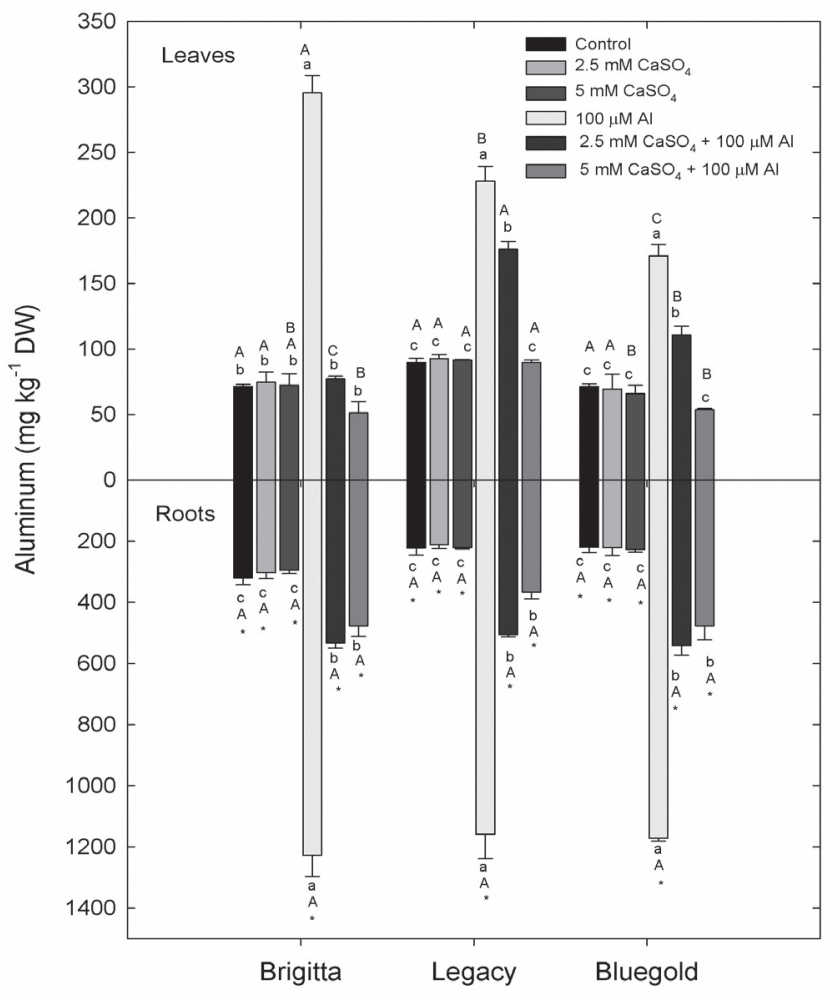

Figure 1. Aluminum concentrations in leaves and roots of three cultivars of highbush blueberry under $\mathrm{Al}$ and $\mathrm{CaSO}_{4}$ treatments. Values represent means $\pm \mathrm{SE}(\mathrm{n}=5)$. Different lower case letters indicate significant differences $(p \leq 0.05)$ between treatments within cultivars and plant tissue. Different upper case letters show differences $(p \leq 0.05)$ between cultivars within treatments and plant tissues. Asterisk $\left(^{*}\right)$ indicates statistically significant differences between tissues (leaves and roots) for the same cultivar and treatments.

\section{Calcium concentrations}

The most striking differences in $\mathrm{Ca}$ concentrations were between the cultivars with cv Brigitta having the by far highest $\mathrm{Ca}$ concentrations in the roots (Figure 2). Cultivar Legacy had the lowest $\mathrm{Ca}$ concentrations in the leaves which did show differences with the two other cultivars. Al treatment reduced the leaf $\mathrm{Ca}$ concentrations in $\mathrm{cv}$. Bluegold more than in cv. Brigitta, but not in cv Legacy. In the roots, $\mathrm{Al}$ supply decreased $\mathrm{Ca}$ concentrations particularly in cv. Brigitta. Likewise, in all cultivars, under $\mathrm{Al}$ supply $\mathrm{CaSO}_{4}$ application restored the $\mathrm{Ca}$ concentrations in the leaves and the roots almost to the control levels (Figure 2). ANOVA revealed a significant interaction between cultivars and treatments for $\mathrm{Ca}$ concentrations in leaves and roots $(p=0.001)$. 


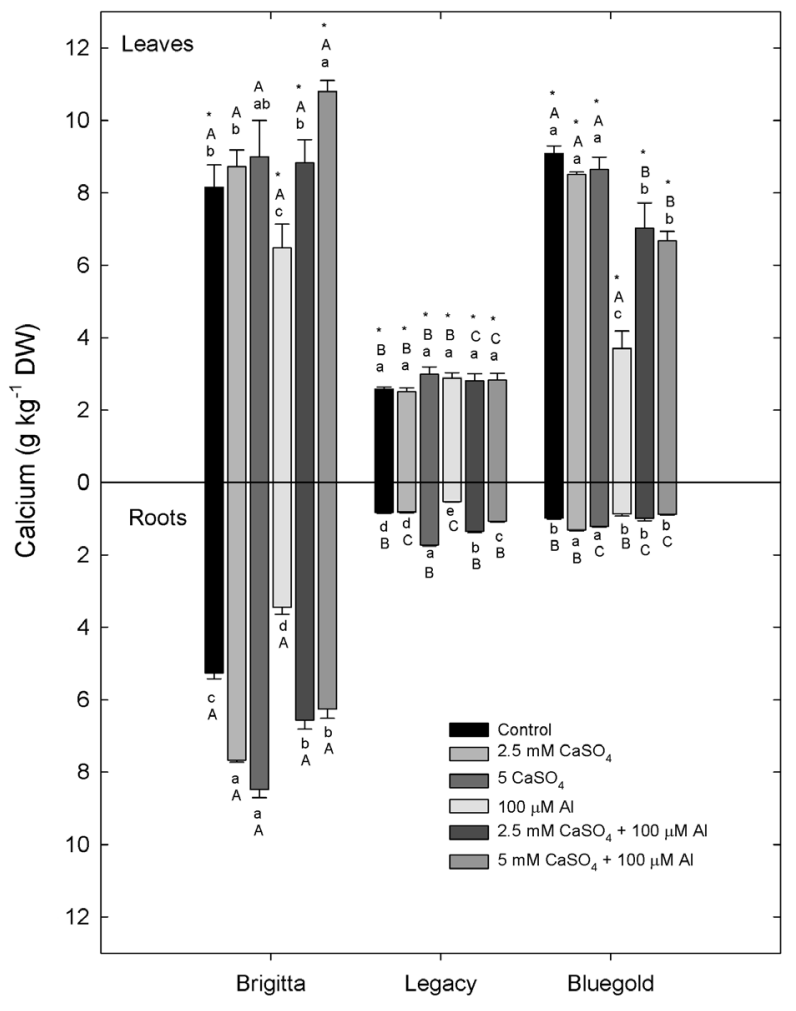

Figure 2. Calcium concentrations in leaves and roots of three cultivars of highbush blueberry under different treatments. Values represent means $\pm \mathrm{SE}(\mathrm{n}=5)$. Different lower case letters indicate statistically significant differences $(p \leq 0.05)$ between treatments for the same cultivar and tissue. Different upper case letters show differences $(p \leq 0.05)$ between cultivars for the same treatments and tissue. Asterisk $(*)$ indicates statistically significant differences between tissues (leaves and roots) for the same cultivar and treatments.

\section{Sulfur concentrations}

Application of $\mathrm{CaSO}_{4}$ enhanced $\mathrm{S}$ concentrations in the leaves in all cultivars; in roots only cv. Bluegold responded with increased $\mathrm{S}$ concentrations (Figure 3). Al supply did not affect the $\mathrm{S}$ concentrations nei- ther in leaves nor in roots with the exception of $\mathrm{cv}$. Bluegold, where $\mathrm{Al}$ prevented an increase in $\mathrm{S}$ concentrations in leaves at both $\mathrm{CaSO}_{4}$ supplies (Figure $3)$. Roots and leaves S content showed a statistically significant interaction between cultivar and treatments $(p<0.001)$. 


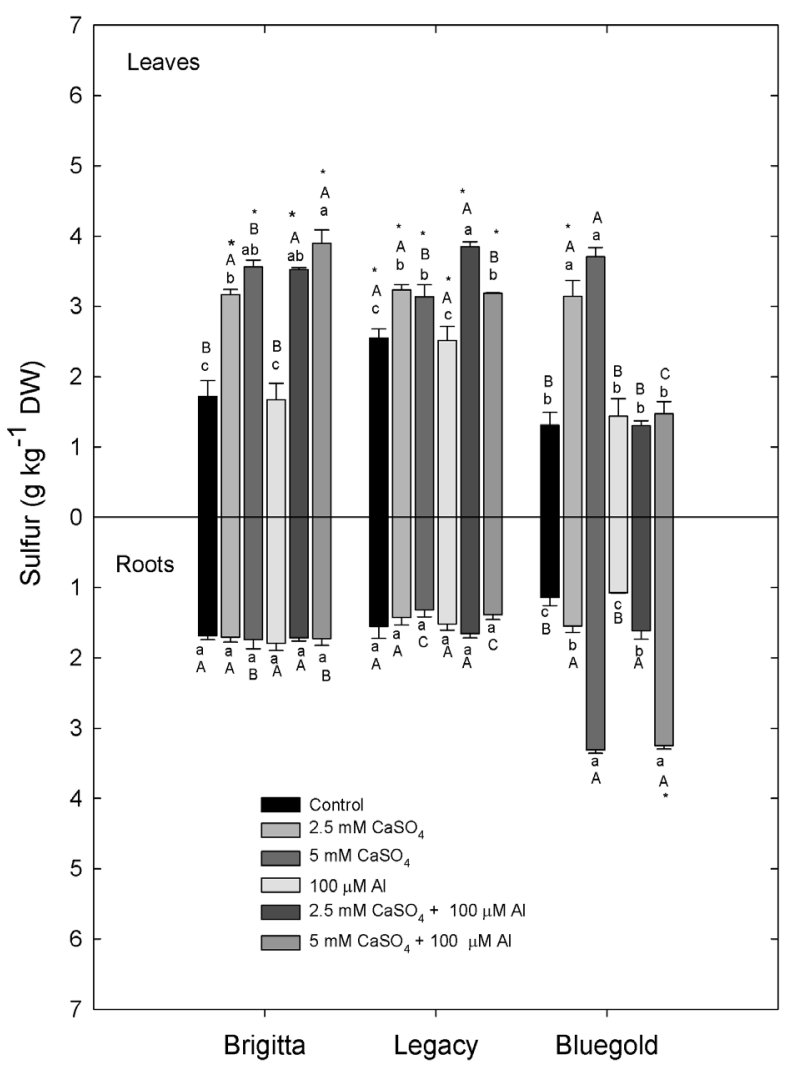

Figure 3. Sulfur concentrations in leaves and roots of three cultivars of highbush blueberry under different treatments. Values represent the average of five replicates $\pm \mathrm{SE}(\mathrm{n}=5)$. Different lower case letters indicate statistically significant differences $(p \leq 0.05)$ between treatments for the same cultivar and tissue. Different upper case letters show differences $(p \leq 0.05)$ between cultivars for the same treatments and tissue. Asterisk $(*)$ indicates statistically significant differ ences between tissues (leaves and roots) for the same cultivar and treatments.

\subsection{Physiological and biochemical analysis}

\section{Mean relative growth rate}

In cv. Legacy, mean relative growth rate (MRGR) was not affected neither by $\mathrm{Al}$ nor $\mathrm{CaSO}_{4}$ treatments (Figure 4). In contrast, $\mathrm{Al}$ treatment significantly reduced MRGR in cvs Brigitta and Bluegold, whereas $\mathrm{CaSO}_{4}$ supply restored the Al-reduced MRGR in these cultivars. Surprisingly, in Bluegold the highest $\mathrm{CaSO}_{4}$ rate decreased significantly the MRGR in absence of Al compared to the control (Figure 4). For this physiological parameter statistically significant interaction between cultivars and treatments were found $(p=$ $0.001)$. 


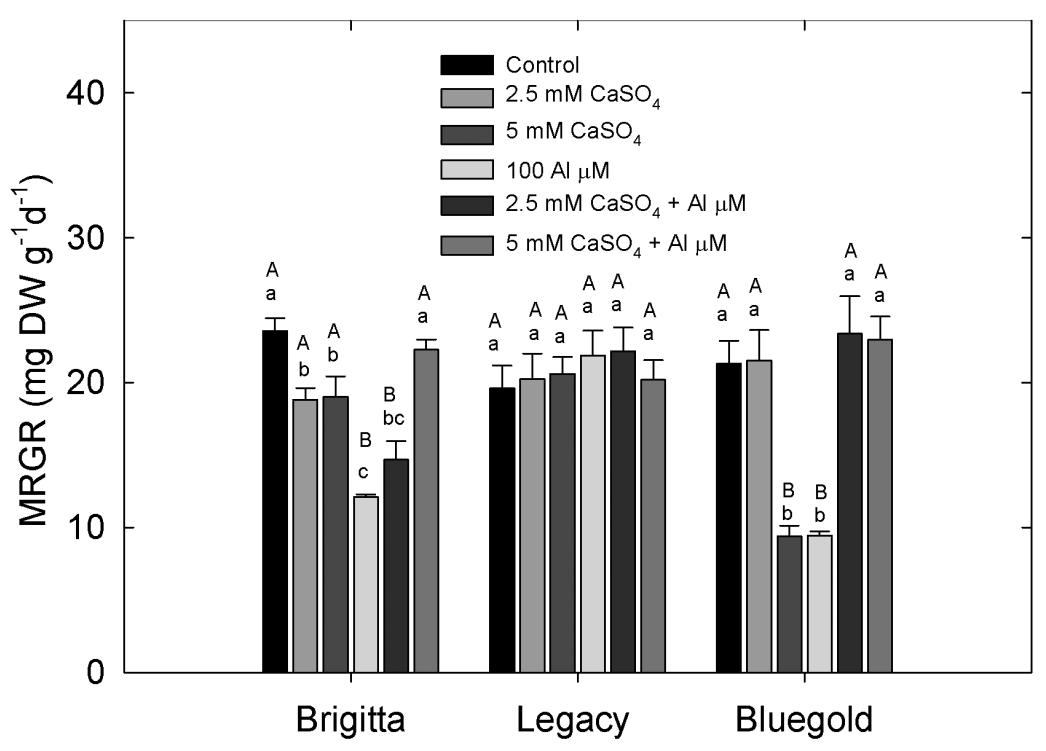

Figure 4. Mean relative growth rate (MRGR) of three cultivars of highbush blueberry grown for 15 days under different treatments. Values represent the means \pm SE $(n=5)$. Different lower case letters indicate statistically significant differences $(p \leq 0.05)$ between treatments within cultivars. Different upper case letters show differences $(p \leq 0.05)$ between cultivars within treatments.

$\mathrm{CO}_{2}$ assimilation

In all cultivars the $\mathrm{CO}_{2}$ assimilation rate of the controls remained constant over the treatment time at about 8 $\mu \mathrm{mol} \mathrm{CO} \mathrm{m}^{-2} \mathrm{~s}^{-1}$ (Figure 5). Al treatment reduced the assimilation rate after one day but recovered to the control level in cvs Brigitta and Legacy. However, in cv. Bluegold the assimilation rate continued to decrease up to 10 days of $\mathrm{Al}$ treatment and remained at this low level until treatment end. Both $\mathrm{CaSO}_{4}$ treatments partly restored the Al-induced decrease in assimilation rate in Bluegold, but not at the same degree as in the other cultivars. ANOVA revealed a significant interaction between cultivars and treatments for all times $(p<0.01)$ with exception for 1 day $(p=0.139)$. Furthermore, ANOVA also revealed a statistically significant interaction between times and treatments in Bluegold and Legacy $(p<0.01)$, but not for Brigitta $(p=0.988)$. 


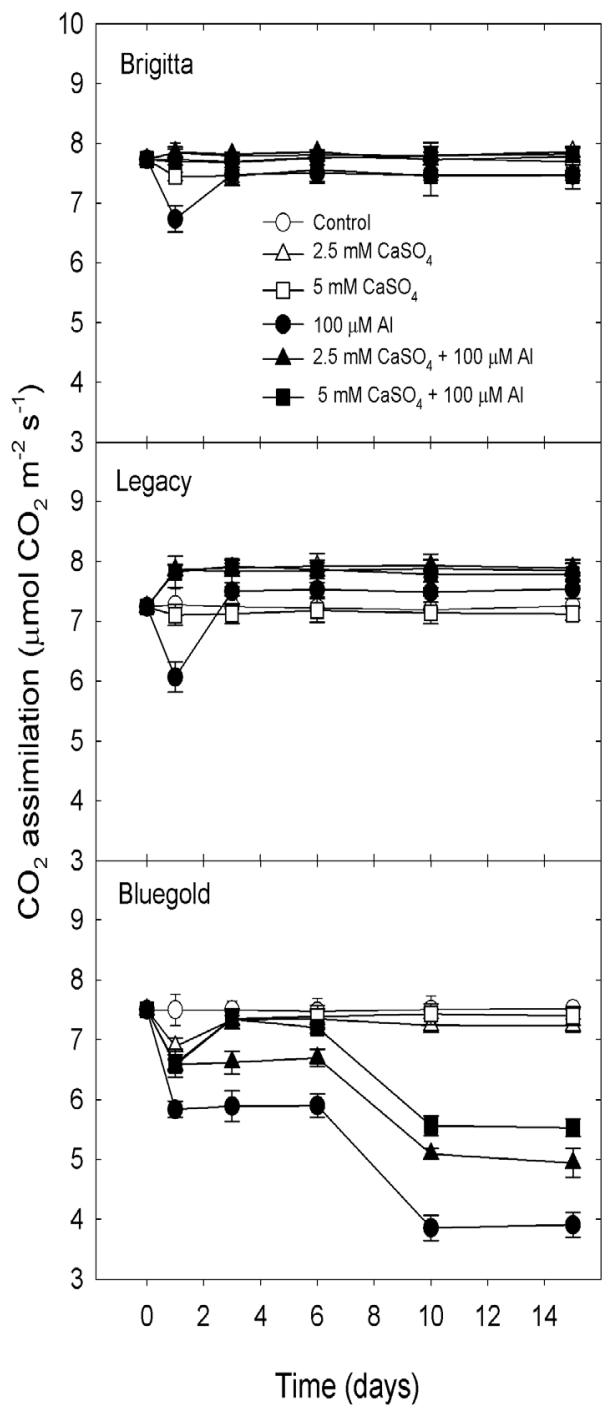

Figure 5. Effect of $\mathrm{Al}$ and $\mathrm{CaSO}_{4}$ treatment on $\mathrm{CO}_{2}$ assimilation rate of leaves of three cultivars of highbush blueberry during the treatment period. Values represent means $\pm \mathrm{SE}(\mathrm{n}=5)$.

\section{Photochemical efficiency of PSII}

The maximum quantum yield $(\mathrm{Fv} / \mathrm{Fm})$ of the three cultivars did not vary under the different treatments and times remaining at around 0.8 (data not shown) a value which is indicative of healthy plants. Nonethe- less, the effective quantum yield (ФPSII) and the electron transport rate (ETR) responded to the $\mathrm{CaSO}_{4}$ and Al treatments in a cultivar-specific way (Figure 6). In cvs Legacy and Brigitta, $\mathrm{CaSO}_{4}$ and their respective combination with $\mathrm{Al}$ reduced DPSII and ETR after one day of treatment, recovering to the control level 
up to 15 days. However, in Bluegold $\mathrm{CaSO}_{4}$ reduced ФPSII and ETR at the first day with recovery only at both $\mathrm{CaSO}_{4}$ levels. Aluminum supply equally reduced both photochemical parameters; however, no recovery occurred at the end of experiment in cvs Brigitta and Bluegold. Increasing the $\mathrm{CaSO}_{4}$ supply counteracted the negative $\mathrm{Al}$ impact completely in cv Legacy, partly in Brigitta, but not in cv Bluegold (Figure 6).
For the photochemical parameters (ФPSII and ETR) a statistically significant interaction between cultivar and treatment was found $(p<0.01)$. For ФPSII of the three cultivars the effect of different levels of time depends on what level of treatment is present $(p<0.01)$. Similarly, for ETR this interaction occurs only in Brigitta and Bluegold $(p<0.01)$, but not in Legacy $(p=0.374)$.

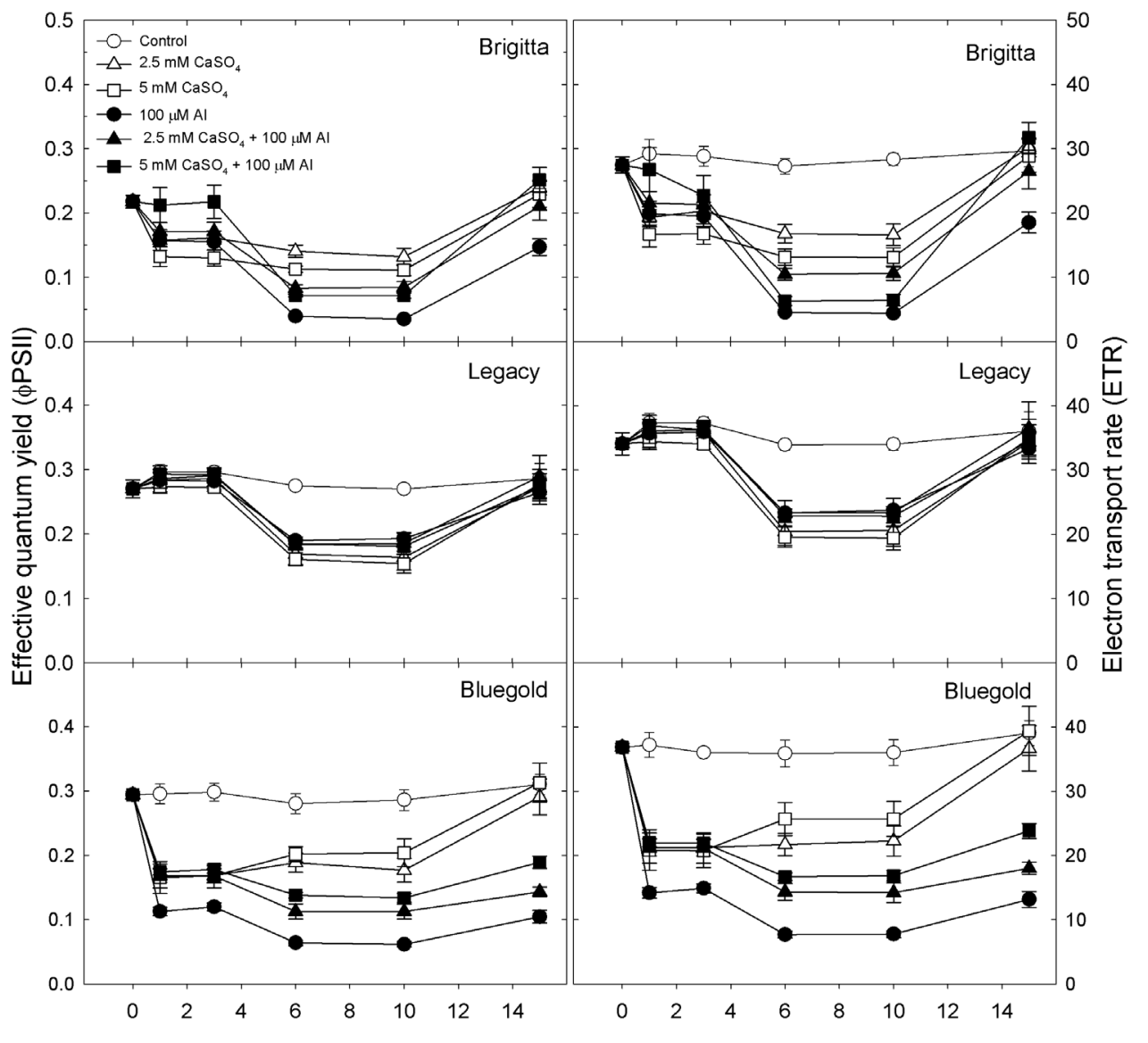

Figure 6. Changes in the effective quantum yield (ФPSII) and electron transport rate (ETR) of three cultivars of highbush blueberry at different times under different treatments. Values represent the average of five replicates \pm SE. 


\section{Lipid peroxidation}

Leaves showed higher lipid peroxidation than roots in all cultivars (Figure 7). Aluminum-treated plants presented the highest lipid peroxidation in the investigated cultivars. Both $\mathrm{CaSO}_{4}$ amendments improved significantly the lipid peroxidation of leaves in cvs Brigitta and Legacy, whereas in Bluegold this occurred only by the highest $\mathrm{CaSO}_{4}$ level (Figure 7). Aluminum treatment significantly enhanced lipid peroxidation in the roots of all cultivars, but several fold more in cvs Brigitta and Bluegold than in cv. Legacy, which showed generally very low levels of lipid peroxidation (Figure 7). Application of $\mathrm{CaSO}_{4}$ alleviated the lipid peroxidation induced by the $\mathrm{Al}$ treatment in cv. Legacy but only partly in cvs Brigitta and Bluegold. For shoots and roots there was statistically significant interaction between cultivars and treatments for lipid peroxidation $(p<0.01)$. Likewise, in the three cultivars the effect of different levels of treatment depends on the plant organ $(p<0.01)$.

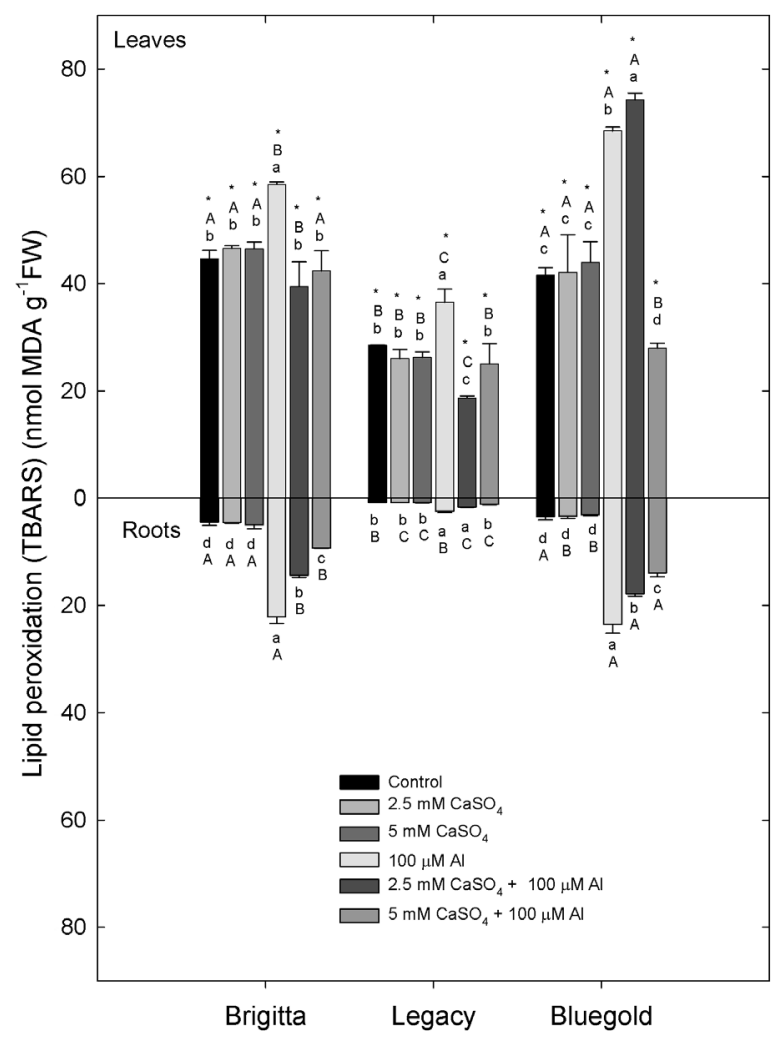

Figure 7. Lipid peroxidation measured as malondialdehyde (MDA) concentration of roots of highbush blueberry cultivars grown for 15 days under different treatments. Values are means \pm SE $(n=5)$. Different lower case letters indicate statistically significant differences $(p \leq 0.05)$ between treatments within cultivars. Different upper case letters show differences $(p \leq 0.05)$ between cultivars within treatments. Asterisk $(*)$ indicates statistically significant differences between tissues (leaves and roots) for the same cultivar and treatments. 


\section{Radical scavenging capacity}

Leaves of all three cultivars showed a higher radical scavenging activity (RSA) than roots independent on the treatment (Figure 8). In cv. Brigitta, Al treatment increased RSA in shoots and roots significantly, an effect which was further enhanced by the application of $\mathrm{CaSO}_{4}$. Cultivars Legacy and Bluegold did not respond to $\mathrm{Al}$ supply, but the response to $\mathrm{CaSO}_{4}$ was similar but weaker than in cv. Brigitta. Particularly, in cv Bluegold RSA was least responsive to the treatments (Figure 8). A statistically significant interaction among cultivars and treatments were found for RSA in roots and leaves $(p \leq 0.001)$.

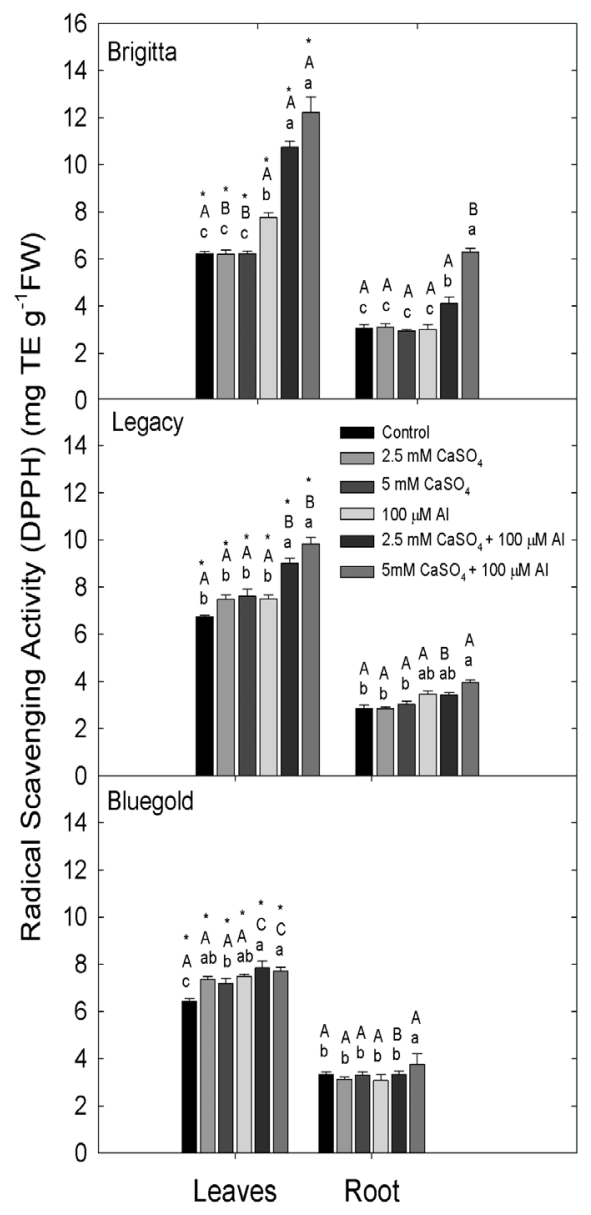

Figure 8. Radical scavenging activity of leaves and roots measured as Trolox equivalents (TE) of highbush blueberry cultivars grown for 15 days under different treatments. Values are means $\pm \mathrm{SE}(\mathrm{n}=5)$. Different lower case letters indicate statistically significant differences $(p \leq 0.05)$ between treatments within cultivars and tissues (leaves and roots). Different upper case letters show differences $(p \leq 0.05)$ between cultivars within treatments and tissues. Asterisk (*) indicates statistically significant differences between tissues for the same cultivar and treatment. 


\section{Superoxide dismutase activity}

In general, leaves of three cultivars showed higher superoxide dismutase (SOD) activity than roots (Figure 9). In leaves, $\mathrm{CaSO}_{4}$ supply enhanced SOD activity in all cultivars independent on $\mathrm{Al}$ supply (exception cv Legacy where at $5 \mathrm{mM} \mathrm{CaSO}_{4}$ plus Al supply reduced SOD activity to the control level). SOD activity was significantly increased in response to $\mathrm{Al}$ treat- ment only in the cvs Legacy and Bluegold. In roots, the SOD activity responded less to the treatment; the highest SOD activity was found in Bluegold under Al supply, but was reduced by $\mathrm{CaSO}_{4}$ treatment (Figure 9). ANOVA revealed a significant interaction between cultivar and treatment in leaves and roots for SOD activity. Likewise, statistically significant interaction between organs and treatments for all cultivars was found $(p<0.01)$.

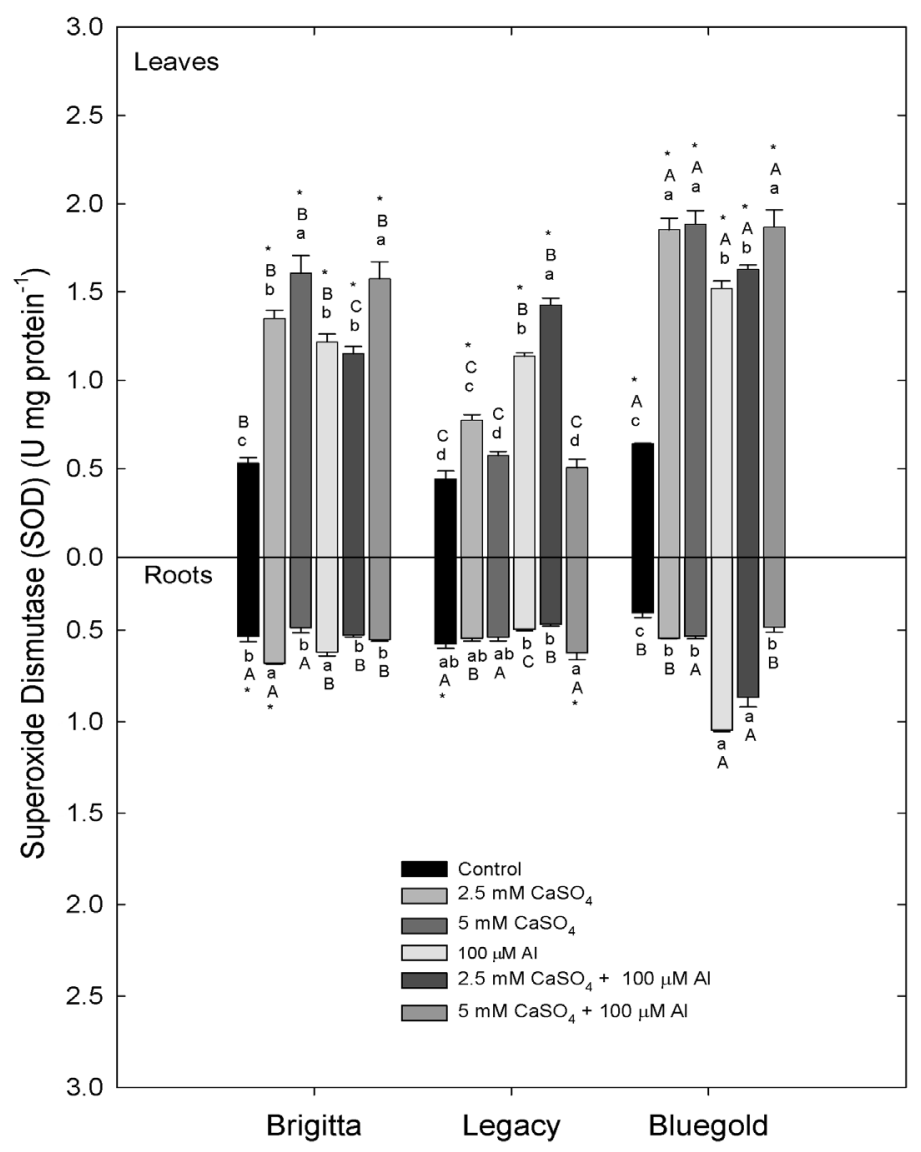

Figure 9. Superoxide dismutase (SOD) activity of leaves and roots of highbush blueberry cultivars grown for 15 days under different treatments. Values are means $\pm S E(n=5)$. Different lower case letters indicate statistically significant differences $(p \leq 0.05)$ between treatments within cultivars and tissues (leaves and roots). Different upper case letters show differences $(p \leq 0.05)$ between cultivars within treatments and tissues. Asterisk $(*)$ indicates statistically significant differences between tissues for the same cultivar and treatment. 


\section{Discussion}

Agronomical practices about use of calcareous amendment to ameliorate the negative effect on plants subjected to $\mathrm{Al}$ toxicity in acid soils has been reported for many crops (Caires et al., 2002; Ritchey and Snuffer, 2002; Caires et al., 2006). However, $\mathrm{CaSO}_{4}$ addition on $V$. corymbosum growing in acid Andisols has been little studied. Our results about the use of $\mathrm{CaSO}_{4}$ amendment in cultivars of this species under Al toxicity showed that this amendment was able to reduce the $\mathrm{Al}$ concentration in both roots and leaves in the three cultivars (Figure 1). Similar results were found in cultivars of barley (Hordeum vulgare L.) by Guo et al. (2006). These authors explained that $\mathrm{Ca}$ addition to nutrient solution reduced the accumulation of $\mathrm{Al}$ in tissues, due to reduction of plant $\mathrm{Al}$ uptake by formation of soluble aluminum sulfate $\left(\mathrm{AlSO}_{4}^{+}\right)$ complexes in nutrient solution, which are harmless to plants (Mathews and Joost, 1989; Carvalho and van Raig, 1997).

Based on the Ca concentrations of tissues, blueberry was considered as a calcifuge species by Hanson and Berkheimer (2004). These authors reported that healthy plants of this species could contain a foliar Ca level from 3.0 to $8.0 \mathrm{~g} \mathrm{~kg}^{-1} \mathrm{DW}$ (0.3 to $0.8 \%$ ), whereas for apple trees (Malus domestica) growing in an Andisol of Southern Chile, von Bennewitz et al. (2011) reported a foliar Ca concentration of.9.9 $\mathrm{g} \mathrm{kg} \mathrm{g}^{-1}$ DW . In our study, Ca concentration of leaves was situated near to these values, depending on cultivar, showing generally higher $\mathrm{Ca}$ concentration than the upper limits reported by these authors in cv Brigitta. It is important to mention that these values were reached even under toxic $\mathrm{Al}$ in presence of the highest $\mathrm{CaSO}_{4}$ concentration of nutrient solution (Figure 2). Also in roots of Brigitta, an effect of $\mathrm{CaSO}_{4}$ amendment was evident in presence of toxic $\mathrm{Al}$ concentration. The lowest $\mathrm{Ca}$ concentrations of roots were found in the most Al-sensitive cultivar (Bluegold) and the highest in the Al-resistant cv Brigitta. Rout et al. (2001) reported that Al-sensitive cultivars of wheat (Triticum aestivum L.) exhibited a lower efficiency in uptake, translocation and utilization of $\mathrm{Ca}$ and $\mathrm{P}$ than the Altolerant cultivars. Furthermore, in our study foliar and root $\mathrm{Ca}$ concentrations in cultivar Bluegold and Brigitta were significantly negatively correlated with $\mathrm{Al}$ concentration ( $r=-0.7$ and -0.6 for leaves and roots, respectively). These results agree with the results of Rengel and Zhang (2003), who reported that Ca addition efficiently reduced $\mathrm{Al}$ concentrations in different tissues by decline of plant $\mathrm{Al}$ uptake. The effective role of $\mathrm{CaSO}_{4}$ in amelioration of $\mathrm{Al}$ toxicity was also confirmed by Chutichudet et al. (2009).

Gypsum $\left(\mathrm{CaSO}_{4}\right)$ has been recognized as a nutrient source of sulfur ( 17\%) (Mathews and Joost, 1989). Our findings showed similar foliar ranges of $S$ concentrations in leaves under gypsum addition compared to those reported by Sanderson et al. (1995) for lowbush blueberry (Vaccinium angustifolium) leaves ( 0.7 to $3.8 \mathrm{~g} \mathrm{~kg}^{-1} \mathrm{DW}$ ). Likewise, high S concentrations were found in the three investigated cultivars with $\mathrm{CaSO}_{4}$ amendment. Similar results are reported in ryegrass by Mora et al. (2005). In our work, it is remarkable that Bluegold showed a higher S concentration of leaves which was positively and statistically significant correlated with the $\mathrm{CO}_{2}$ assimilation $(\mathrm{r}=0.6, p=0.007)$, whereas in the other cultivars a same tendency was found, but without statistical significance. In Brassica plants, the rate of photosynthesis was higher with S supply (59.2-68.3\%) than without S (Mobin et al. 2010). These authors explained this behavior by a closure of stomata under $\mathrm{S}$ deficiency inhibiting the $\mathrm{CO}_{2}$ uptake and thus restricting the carbon assimilation.

The first and most recognized effect of Al toxicity in plants is the inhibition of the division and elongation of meristematic root cells and thereby, a reduc- 
tion in root growth (Panda et al. 2003; Mora et al., 2006). Reyes-Díaz et al. (2009; 2010) subjected the same three blueberry cultivars (Brigitta, Legacy and Bluegold) used in this work to short- and long-term $\mathrm{Al}$ excess in hydroponics. Cultivar Legacy showed a greater $\mathrm{Al}$ accumulation in leaves and roots, maintaining its growth iun contrast to the other cultivars. This feature was directly associated with the degree of $\mathrm{Al}$ tolerance, suggesting that Legacy is most suitable to be established in acid soils under Al toxicity.

According with our study on V. corymbosum, Brigitta and Bluegold showed a reduced MRGR when plants were subjected to $100 \mu \mathrm{M} \mathrm{Al}$, whereas in plants additionally supplied with $\mathrm{CaSO}_{4}$ MRGR was restored (Figure 4). An increased root and shoot growth was reported for soybean (Glycine max) by Sanzonowicz et al. (1998), indicating that an increase in $\mathrm{Ca}$ concentration (using $\mathrm{CaSO}_{4}$ as $\mathrm{Ca}$ source) decreased the inhibitory effects of $\mathrm{H}^{+}$and $\mathrm{Al}$ in roots, because of an increased ionic strength and a reduced predicted activity of monomeric $\mathrm{Al}$ species.

The most evident changes in the photosynthetic performance $\left(\mathrm{CO}_{2}\right.$ assimilation and photochemical parameters) under the effect of $\mathrm{Al}$ were exhibited by the Al-sensitive cv Bluegold, where these parameters decreased and did not show full recovery in presence of gypsum amendment at the end of experiment (Figures 5 and 6). Akaya and Takenaka (2001) suggested that the effect of $\mathrm{Al}$ on reduced root function of Quercus glauca was not only directly associated to a decrease of photosynthesis rate, but rather to mineral element deficiency plus high Al concentration in tissues. Reich et al. (1994) evaluated net photosynthesis in scots pine (Pinus sylvestris) under excessive soil $\mathrm{Al}$ and deficient $\mathrm{Ca}$ and $\mathrm{Mg}$ levels in needles, which resulted in a reduced photosynthetic capacity and increased respiration. Our findings showed no effect of toxic $\mathrm{Al}$ on the photosynthetic performance of the Al-resistant cv Legacy, whereas in cv Brigitta, only a slight recovery of this process by the gypsum application at the end of treatment became evident. In Citrus grandis the toxic effect of $\mathrm{Al}$ showed decreased photochemical parameters of PSII such as Fv/Fm, ФPSII and ETR, by reduction of chlorophyll contents and enhanced energy dissipation (Jiang et al. 2008). These authors also suggested that decreased photosynthesis performance could be related to a photoinhibition in both donor and acceptor sites of PSII.

Some stresses trigger changes in antioxidant responses suggesting an induction of these mitigation mechanisms in response to ROS generation at the cellular level (Blokhina et al. 2003). In our study, RSA and SOD were differentially activated in response to Al stress in the three cultivars. Statistically significant correlations between SOD and Al concentration of leaves were obtained only in Legacy $(r$ $=0.821 ; p<0.001)$, while in Bluegold a statistically significant correlation between SOD and Al concentration and lipid peroxidation at root level was found $(\mathrm{r}=0.85 ; p<0.001$ and $\mathrm{r}=0.84 ; p<0.001$, respectively). These results suggest that in the case of Legacy, SOD would be an important defense mechanism against $\mathrm{Al}$ stress by helping to maintain its growth and photosynthetic capacity. On the contrary, in the Al-sensitive cultivar (Bluegold) SOD activity is only a stress response to the $\mathrm{Al}$ treatment. It is know that SOD constitutes the first line of defense against ROS at the cellular level, and it has a high significance as an antioxidant defense mechanism (Alscher et al. 2002). Notwithstanding, it is important to mention that contradictory observations about SOD activity in different plant species under stresses have been reported, which may be explained by their different stress tolerance (Blokhina et al. 2003). 


\section{Conclusions}

Based on the measured parameters it is concluded that gypsum amendment was efficient in complete recovery from the toxic $\mathrm{Al}$ effect in the Al-resistant and medium Al-resistant cultivars Legacy and Brigitta, respectively, but was only partly efficient in the Al-sensitive cv. Bluegold. With respect to Bluegold further investigation at the long-term may be useful to obtain a better recovery. Perhaps this cultivar needs a longer time to adjust its response mechanism. However, gypsum amendment may be a good alternative liming to alleviate $\mathrm{Al}$ toxicity in the long-term in the Al-sensitive cultivars and may provide a good source of nutrients such as $\mathrm{Ca}$ and $\mathrm{S}$.

\section{Acknowledgements}

We would like to thank FONDECYT Nº11080231 Project for financial support. C. Meriño-Gergichevich was supported by a PhD fellowship from CONICYTChile. E. Alarcón was supported by a PhD fellowship from MECESUP FRO 0601.

\section{References}

Akaya, M., Takenaka, C. 2001. Effects of aluminum stress on photosynthesis of Quercus glauca Thumb. Pant Soil. 237, 137-146.

Alscher, R. G., Erturk, N., Heath, L. S. 2002. Role of superoxide dismutases (SODs) in controlling oxidative stress in plants. J. Exp. Bot. 53,1331-1341.

Besoain, M. E. 1999. Los suelos volcánicos y la fertilización fosfatada. p. 13-21. In: E. Besoain M., C. Rojas W. y A. Montenegro B. (eds.). Las rocas fosfóricas y sus posibilidades de uso agrícola en Chile. Colección Libros INIA No2, INIA, Santiago, Chile, 328p.
Blatt; C. R., McRae, K. H. 1997. Marketable yield response of two lowbush blueberries to preplant applications of gypsum, calcitic and dolomitic limestones. J. Small Fruit Viticulture 5, 13 - 26.

Blokhina, O., Virolainen, E., Fagerstedt, K. V. 2003. Antioxidants, oxidative damage, and oxygen deprivation stress: A review. Ann Bot-London 91, 179 - 194.

Bolan, N.S., Adriano D., Curtin, D. 2003. Soil acidification and liming interactions with nutrient and heavy metals transformations and bioavailability. Adv. Agron. 78, 215-272.

Borie, F., Rubio, R. 2003. Total and organic phosphorus in Chilean volcanic soils. Gayana Botanica 60, 69-78.

Bradford, M.M. 1976. A rapid and sensitive method for the quantification of microgram quantities of protein utilizing the principle of protein-dye binding. Anal. Biochem. 72, 248-254.

Caires, E. F., Churka, S., Garbuio, F. J., Ferrari, R. A., Morgano, M. A. 2006. Soybean yield and quality as a function of lime and gypsum applications. Sci. Agric. 63, 370 -379.

Caires, E. F., Feldhaus, I. C., Barth, G., Garbuio, F. J. 2002. Lime and gypsum application on the wheat crop. Scientia Agric. 59, 357 - 364.

Campbell, C. G., Garrido, F., Illera, V., GarcíaGonzález, M., T. 2006. Transport of $\mathrm{Cd}, \mathrm{Cu}$ and $\mathrm{Pb}$ in an acid soil amended with phosphogypsum, sugar foam and phosphoric rock. Appl. Geochem. $21,1030-1043$.

Carvalho, M. C. S., van Raij, B. 1997. Calcium sulphate, phosphogypsum and calcium carbonate in the amelioration of acid subsoils for root growth. Plant Soil 192, 37 - 48.

Chen, L.S., Qi, Y.-P., Liu, X.-H. 2005. Effects of aluminum on light energy utilization and photoprotective systems in citrus leaves. Ann. Bot.(Lond.) $96,35-41$. 
Chinnici, F., Bendini, A.A., Gaiani, A., Riponi C. 2004. Radical scavenging activities of peels and pulps from cv. Golden delicious apples as related to their phenolic composition. J. Agr. Food Chem. $52,4684-4689$.

Chutichudet, P., Chutichudet, B., Kaewsit, S. 2009. Effect of Gypsum Application on Enzymatic Browning Activity in Lettuce. Pakistan Journal of Biological Sciences 12, 1226-1236.

Delhaize, E., Ryan, P. R. 1995. Aluminum toxicity and tolerance in plants. Plant Physiol. 107, 315 - 321.

Donahue, J.L., Okpodu, C.M., Cramer, C.L., Grabau, E.A., Aslcher, R.G. 1997. Responses of antioxidant to paraquat in pea leaves. Relationships to resistance. Plant Physiol. 113, 249-247.

Du, Z., Bramlage, W.J. 1992. Modified thiobarbituric acid assay for measuring lipidoxidation in sugarrich plant tissue extracts. J. Agr. Food Chem. 40, 1556-1570.

Foy, C. D., Chaney, R. L., White, M. C. 1978. The physiology of metal Al-toxicity in plants. Annu. Rev. Plant Physiol. 29, 511 - 566.

Franzen, D., Rehm, G., Gerwing, J. 2006. Effectiveness of gypsum in the North-central region of the U. S. Extension Service. North Dakota State University. $4 p$.

Guerrero, J.A. 2006. Capacidad antioxidante, fenoles y antocianinas totales e inhibición de Botrytis cinerea Pers. Ex Fr. Por extractos crudos de fruta de cultivares de arandano alto (Vaccinium corymbosum L.) según localidad de la zona Sur de Chile. PhDThesis, Universidad Austral de Chile, Valdivia, Chile.

Guo, T., Chen, Y., Zhang, Y., Jin. Y. 2006. Alleviation of al toxicity in barley by addition of calcium. $\mathrm{Ag}$ ricultural Sciences in China 5, 828-833.

Hanson, E. J., Berkheimer, S. F. 2004. Effect of soil calcium applications on blueberry yield and quality. Small Fruits Review 3, 133 - 139.
Heath, R.L., Packer, L. 1968. Photoperoxidation in isolated chloroplast. I. Kinetics and stoichiometry of fatty acid peroxidation. Arch. Biochem. Biophys. 125, 189-198.

Hoagland, D.R., Arnon, D.I. 1959. The water culture method for growing plants without soil. California Agr. Expt. Sta. 347, 1-32.

Hoffmann, W.A., Poorter, H. 2002. Avoiding bias in calculations of relative growth rate. Ann. BotLondon 90, 37-42.

Illera, V., Garrido, F., Vizcayno, C., García-González, M. T. 2004. Field application of industrial byproducts as Al-toxicity amendments: chemical and mineralogical implications. Eur. J. Soil Sci. $55,681-692$.

INE. 1998. VI Censo Nacional Agropecuario 1997. INE, Santiago, Chile, 214 p.

Ireland, G., Wilk, P. 2006. Blueberry production in northern NSW. Primefact 195. 10 Oct. 2008. $<$ http://www.dpi.nsw.gov.au/_data/assets/pdf_ file/ 0005/ 90356/ Blueberry-production-in-northern-NSW.pdf> .

Jiang, H. X., Chen, L. S., Zheng, J. G., Han, S., Tang, N., Smith, B. 2008. Aluminum-induced effects on Photosystem II photochemistry in Citrus leaves assessed by the chlorophyll a fluorescence transient. Tree Physiology 28, 1863-1871.

Kochian, L. 1995. Cellular mechanisms of aluminum toxicity and resistance in plants. Annu. Rev. Plant Physiol. Mol. Biol. 46, 237-260.

Korcak, R. F. 1992. Short-term response of Blueberry to elevated soil calcium. Journal of small fruit and viticulture (USA). Vol. 1(2): 9-20.

Ma, J. F. 2005. Physiological mechanisms of Al resistance in higher plants. Soil Sci. Plant Nutr. 61. 609-612. 
Mathews, B. W., Joost, R. E. 1989. Use of sulfate salts to reduce subsoil aluminum toxicity: a review. J Haw Pac Agri 2, 24 - 30.

Maxwell, K., Johnson, G.N. 2000. Chlorophyll fluorescence-a practical guide. J. Exp. Bot. 51, 659-668.

Meriño-Gergichevich, C., Alberdi, M., Ivanov, A.G., Reyes-Díaz, M. 2010. $\mathrm{Al}^{3+}-\mathrm{Ca}^{2+}$ Interaction in plants growing in acid soils: Al-phytotoxicity response to calcareous amendments. J. Soil. Sci. Plant Nutr. 10, 217 -243.

Mobin, M., College, K. P. G. 2010. Photosynthetic and physiological responses of indian mustard (Brassica juncea L. CZERN \& COSS) Plants as affected by sulfur starvation. Electronic Journal of Environmental, Agricultural and Food Chemistry 9, 1316-1321.

Mora, M. L., Schnettler, B., Demanet, R. 1999. Effect of liming and gypsum on soil chemistry, yield, and mineral composition of ryegrass grown in an acidic Andisol. Commun. Soil Sci. Plant Anal. 30, 1251 - 1266.

Mora, M. L., Cartes, P., Demanet, R., Cornforth I. S. 2002. Effects of lime and gypsum on pasture growth and composition on an acid Andisol in Chile, South America. Commun. Soil Sci. Plant Anal. 33, 2069 - 2081.

Mora, M., Alfaro, M., Williams, P.H., Stehr, W., Demanet, R. 2004. Effect of fertilizer input on soil acidification in relation to growth and chemical composition of a pasture and animal production. R.C.SueloNutr.Veg.4:29-40.

Mora, M. L., Demanet, R., Vistoso, E., Gallardo, F. 2005. Influence of sulfate concentration in mineral solution on ryegrass grown at different $\mathrm{pH}$ and aluminum levels. Journal Of Plant Nutrition $28,1117-1132$.

Mora, M. L., Alfaro, M. A., Jarvis, S. C., R. Demanet, R., Cartes, P. 2006. Soil aluminium availability in
Andisols of southern Chile and its effect on forage production and animal metabolism Soil Use and Management 22, 95-101.

Panda, S. K., Singha, L. B., Khan, M. H. 2003. Does aluminium phytotoxicity induce oxidative stress in greengram (Vigna radiata)? Bulg. J. Plant Physiol. 29, 77 - 86.

Pavlovkin, J., Pal'ove-Balang, P., Kolarovič, L., Zelinová, V. 2009. Growth and functional responses of different cultivars of Lotus corniculatus to aluminium and low pH stress. J. Plant Physiol. 166, 1479-1487.

Peixoto, H. P., da Matta, F. M., da Matta, J. C. 2002. Responses of the photosynthetic apparatus to aluminum stress in two sorghum cultivars. J. Plant Nutr. 25, $821-832$.

Pereira, W.E., de Siqueira, D.L., Martinez, C.A., Puiatti, M. 2000. Gas exchange and chlorophyll fluorescence in four citrus rootstocks under aluminum stress. J. Plant Physiol. 157, 513-520.

Poschenrieder, C., Gunsé, B., Corrales, I., Barceló, J. 2008. A glance into aluminum toxicity and resistance in plants. Sci. Total Environ. 400, 356-368.

Rangel, A. F., Rao, I. M., Horst, W. J. 2007. Spatial aluminium sensitivity of root apices of two common bean (Phaseolus vulgaris L.) genotypes with contrasting aluminium resistance. J. Exp. Bot. 58, 3895-3904.

Reich, P. B., Oleksyn, J., Tjoelker, M. G. 1994. Relationship of aluminum and calcium to net $\mathrm{CO}_{2}$ exchange among diverse scots pine provenances under pollution stress in Poland. Oecologia 97, $82-92$.

Rengel, Z., Zhang, W. H. 2003. Role of dynamics of intracellular calcium in aluminum-toxicity syndrome. New Phytol. 159, 295 - 314.

Reyes-Díaz, M., Alberdi, M., Mora, M. L. 2009. Short-term aluminum stress differentially affects the photochemical efficiency of photosystem II 
in highbush blueberry genotypes. J. Amer. Soc. Hort. Sci. 134, $14-21$.

Reyes-Díaz, M., Inostroza-Blancheteau, C., Millaleo, R., Cruces, E., Wulff-Zottele, C., Alberdi, M., Mora, M.L. 2010. Long-term aluminum exposure effects on physiological and biochemical features of highbush blueberry cultivars. J. Amer. Soc. Hort. Sci. 135, 212-222.

Ritchey, K. D., Snuffer, J. D. 2002. Limestone, gypsum, and magnesium oxide influence restoration of an abandoned Appalachian pasture. Agron. J. 94, 830 - 839 .

Rout, G. R., Samantara, S., Das, P. 2001. Aluminium toxicity in plants: a review. Agronomie. 21, 3-21.

Ryan, P. R., Delhaize, E. 2010. The convergent evolution of aluminium resistance in plants exploits a convenient currency. Funct. Plant Biol. 37, 275 -284 .

Sadzawka, A., Grez, R., Carrasco, M., Mora, M. 2007. Métodos de análisis de tejidos vegetales. 53p. Santiago, Chile, Comisión de Normalización y Acreditación Sociedad Chilena de la Ciencia del Suelo.

Sanderson, K. R., Carterl, M. R., lvany, J. A. 1995. Effects of gypsum on yield and nutrient status of native lowbush blueberry. Can.. J. plant Sci. 26, 361-366.

Sanzonowicz, C., Smyth, T. J., Israel, D. W. 1998. Calcium alleviation of hydrogen and

aluminum inhibition of soybean root extension from limed soil into acid subsurface solutions. J. Plant Nutr. 21, 785 - 804.

Shao, H. B, Chu, L. Y., Shao, M. A., Jaleel, C. A., Mi, H. M. 2008. Higher plant antioxidants and redox signaling under environmental stresses. C. R. Biologies 331,433 - 441 .
Sivaguru, M., Horst, W.J. 1998. The transition zone is the most aluminium-sensitive apical root zone of Zea mays L. Plant Physiol. 116, 155-163.

Suzuki, A., Miura, A., Aoba, K. 1999. Effects of Aluminum, Calcium, and Phosphate on Shoot Growth, Viability, and Aluminum Distribution in the Root Apices in Highbush Blueberry Cultured in vitro. J Japan Soc Hort Sci 68, 937-941.

Takahashi, T., Ikeda, Y., Nakamura, H., Nanzyo, M. 2006a. Efficiency of gypsum application to acid Andosols estimated using aluminum release rates and plant root growth. J. Soil Sci. Plant Nutr. 52, $584-592$.

Takahashi, T., Ikeda, T., Fujita, K., Nanzyo, M. 2006b. Effect of liming on organically complexed aluminum of nonallophanic Andosols from northeastern Japan. Geoderma 130, 26 - 34.

Tamás, L., Huttová, J., Mistrík, I., Šimonovicová, M. 2006. Aluminium-induced drought and oxidative stress in barley roots. J. Plant Physiol. 163, 781-784.

Toma, M., Saigusa, M. 1997. Effects of phosphogypsum on ameliorating strongly acid nonallophanic Andosols. Plant Soil 192, 49 - 55.

von Bennewitz, E., Cooper, T., Benavides, C., Losak., T., Hlusek, J. 2011. response of "Jonagold" apple trees to $\mathrm{Ca}, \mathrm{K}$ and $\mathrm{Mg}$ fertilization in an Andisol in southern Chile. J. Soil. Sci. Plant Nutr. 11, 217 -243 .

Yamamoto, Y., Kobayashi, Y., Matsumoto, H. 2001. Lipid peroxidation is an early symptom triggered by aluminum, but not the primary cause of elongation inhibition in pea roots. PlantPhysiol. 125, 199-208.

Yang, W. Q., Goulart, B., Demchak, K. 1996. The effect of aluminium and media on the growth of mycorrhizai and nonmycorrhizal highbush blueberry plantlets. Plant and Soil 183, 301-308. 